\title{
EVALUASI USABILITY SITUS WEB KEMENKUMHAM KANTOR WILAYAH JAMBI DENGAN METODE USABILITY TEST DAN SYSTEM USABILITY SCALE
}

\author{
Beny*1, Herti Yani $^{2}$, Gessy Mahargya Ningrum ${ }^{3}$ \\ ${ }^{1}$ STIKOM Dinamika Bangsa, Jl.Jendral Sudirman - Thehok, Telp. (0741) 35095 \\ Jurusan Sistem Informasi, STIKOM Dinamika Bangsa, Jambi \\ e-mail: *1 beny@ stikom-db.ac.id, ${ }^{2}$ adeherti@yahoo.com, ${ }^{3}$ gessymahargya11@gmail.com
}

\begin{abstract}
Abstrak- Situs Kemenkumham Jambi merupakan situs yang memberikan informasi mengenai profil Kanwil Kemenkumham Jambi dan memberikan layanan pengaduan yang dapat di akses oleh masyarakat. Permasalahan yang ditemukan adalah tidak semua informasi tersedia didalam situs tersebut dan sebagian masyarakat belum banyak yang mengetahui fungsi dari layanan yang ada pada situs tersebut. Tujuan dari penelitian ini adalah untuk mengetahui tingkat kegunaan (Usability) dari sebuah situs dengan menggunakan metode Usability Testing dan kuesioner System Usability Scale (SUS). Perhitungan dilakukan dengan cara menganalisis skenario yang telah diselesaikan dan menganalisis kuesioner pada masyarakat Jambi, kemudian dihitung berdasarkan formula System Usability Scale (SUS). Selanjutnya, hasil perhitungan dari kuesioner SUS dan Task Scenario yang telah dijalani dan disebarkan kepada 30 responden dijadikan dasar dalam merumuskan saran dan rekomendasi yang tepat. Hasil dari penelitian ini yaitu sebuah saran dan rekomendasi usability dari tampilan situs Kantor Wilayah Kementrian Hukum dan HAM Jambi.
\end{abstract}

Kata kunci-Evaluasi Situs, Usability, Usability Testing, System Usability Scale (SUS).

\section{PENDAHULUAN}

Terus meningkatnya kemudahan akses internet saat ini memungkinkan penyampaian informasi yang semakin cepat kepada masyarakat di Indonesia. Kondisi tersebut memungkinkan lembaga-lembaga pemerintahan untuk dapat berinteraksi secara langsung dengan masyarakat yang membutuhkan. Searah dengan pertumbuhan kecepatan internet saat ini juga diikuti dengan adanya perkembangan TIK (Teknologi Informasi dan Komunikasi). Kebutuhan akan pemanfaatan perangkat lunak demikian tinggi dalam berbagai organinsasi, termasuk salah satunya dalam bidang pemerintahan.

Kementrian Hukum dan HAM Kantor Wilayah Jambi merupakan Kantor Wilayah yang berada dibawah tanggung jawab kepada Presiden perihal mengelola urusan Hukum dan Hak Asasi manusia. Pada kantor wilayah yang berada di Provinsi Jambi yaitu beralamatkan di Jln. Kapten Sujono, Paal Lima, Kota Jambi mempunyai situs resmi yaitu https://jambi.kemenkumham.go.id/ yang mana situs tersebut dimutahirkan dalam jangka waktu tertentu seputar informasi terbaru kanwil seperti berita terkini, berita unit pusat, berita kementrian, unit pelayanan teknis yang bisa diketahui masyarakat jambi serta menjadi sarana komunikasi berbasis situs dengan menghubungi kontak kanwil kemenkumham jambi yang terdapad di situs tersebut. Masyarakat juga bisa melihat profil, satuan kerja, produk hukum, layanan publik, pusat informasi, survey IKM, dan lain-lain.

Permasalahan awal yang ditemukan pada situs Kemenkumham Kantor Wilayah Jambi ini adalah ketidaklengkapan informasi yang disajikan, seperti informasi satuan kerja yang mana ketika diakses hanya menampilkan halaman kosong yang kadaluarsa, informasi seputar survey IKM yang hanya menampilkan halaman kosong selain itu sebagian masyarakat belum mengetahui fungsi dari situs tersebut dan masyarakat lebih cenderung untuk mencari informasi pada media lain yang dimana informasi tersebut belum tentu benar, untuk itu perlu dilakukan tinjuan langsung kepada masyarakat sebagai pengguna. Penelitian ini menggunakan metode usability testing dengan menggunakan kuisioner SUS (System Usability Scale) untuk menemukan lebih lanjut apakah situs tersebut telah memenuhi standar usability, dan menemukan kesalahan-kesalahan yang ada pada situs tersebut.

\section{LANDASAN TEORI}

\section{A. Usability / Daya Guna}

Kata dasar dari usability adalah berasal dari kata usable yang memiliki arti dapat digunakan dengan baik. Suatu benda atau alat dapat dikatakan berguna dengan baik apabila tingkat kegagalan dalam penggunaannya dapat dihilangkan atau diminimalkan serta memberi manfaat dan keputusan kepada orang yang menggunakannya [1]. Usability adalah salah satu tolok ukur interaktivitas pengalaman pengguna yang terkait dengan antarmuka pengguna seperti sebuah situs atau sebuah perangkat lunak dalam bentuk aplikasi . Sebuah antarmuka sistem atau perangkat lunak dikatakan user-friendly jika antarmuka yang digunakan tersebut mudah dipelajari [2], membantu pekerjaan dan tugas orang yang menggunakannya secara efektif dan efisien, sehingga memuaskan dan menarik ketika digunakan [3][4]. 


\section{B. Usability Testing}

Usability testing adalah pengujian penggunaan terhadap sistem atau produk untuk menemukan permasalahan daya guna atau usability [5][6]. Berdasarkan standar ISO 9421-11 disebutkan bahwa syarat usability yang baik adalah efektif, efisien, dan kepuasan pengguna. Sudah jelas bahwa sebaiknya sebagai pengguna dapat melakukan secara efektif (berpacu pada hasil), efisien (berpacu pada caranya), dan puas (mendapatkan kepuasan) [7].

\section{System Usability Scale (SUS)}

SUS (System Usability Scale) merupakan salah satu alat yang paling sering digunakan untuk menilai kegunaan (Usability) dari suatu sistem ataupun produk [8]. John Brooke mengembangkan System Usability Scale pada tahun 1986 sebagai metode yang praktis [9][10]. System Usability Scale digunakan untuk mengukur usability dikarenakan memiliki beberapa kelebihan, antara lain [10]: a) dapat dikalkulasikan dengan sederhana, dan luaran hasilnya berupa skor 0-100 sehingga lebih mudah dimengerti, b) tidak membutuhkan biaya dalam penggunaannya c) dengan ukuran sampel yang relatif kecil tetap terbukti valid dan reliable.

Metode penilaian System Usability Scale mengharuskan para peserta untuk memberikan tanggapan terhadap semua sepuluh pernyataan. Jika karena alasan tertentu, peserta yang tidak dapat menanggapi suatu item harus memilih titik pusat skala. Langkah awal dalam penilaian System Usability Scale adalah untuk menentukan kontribusi nilai setiap pernyataan yang berkisar dari 0 hingga 4 [11][12].

Tabel 1. Pernyataan SUS [10] [13]

\begin{tabular}{|l|l|}
\hline No & \multicolumn{1}{|c|}{ Pernyataan } \\
\hline R1 & $\begin{array}{l}\text { Saya akan sering mengunjungi / menggunakan } \\
\text { situs ini }\end{array}$ \\
\hline R2 & Saya menilai situs ini terlalu kompleks \\
\hline R3 & Saya menilai situs ini mudah dijelajahi \\
\hline R4 & $\begin{array}{l}\text { Saya butuh bantuan teknis untuk menjelajahi } \\
\text { situs ini }\end{array}$ \\
\hline R5 & $\begin{array}{l}\text { Saya menilai fungsi/fitur yang disediakan situs } \\
\text { ini telah dirancang dan disiapkan dengan baik }\end{array}$ \\
\hline R6 & $\begin{array}{l}\text { Saya menilai terlalu banyak inkonsistensi pada } \\
\text { situs ini }\end{array}$ \\
\hline R7 & $\begin{array}{l}\text { Saya merasa kebanyakan orang akan mudah } \\
\text { menjelajahi situs ini dengan cepat }\end{array}$ \\
\hline R8 & $\begin{array}{l}\text { Saya menilai situs ini sangat rumit untuk } \\
\text { dijelajahi }\end{array}$ \\
\hline R9 & $\begin{array}{l}\text { Saya merasa sangat percaya diri dalam } \\
\text { menjelajahi situs ini }\end{array}$ \\
\hline R10 & $\begin{array}{l}\text { Saya perlu belajar banyak hal sebelum saya } \\
\text { dapat menjelajahi situs ini dengan baik }\end{array}$ \\
\hline
\end{tabular}

Penilaian akhir SUS berupa rentang penilaian dari 0 hingga 100. Rentang nilai 0-100 ini dapat setara dibandingkan dengan skala penilaian lain seperti 1) Adjective Rating dengan rentang penilaian terburuk hingga terbaik [14], 2) Scale Grade dengan rentang F hingga A, dan 3) Acceptability Range dengan rentang Not Acceptable hingga Acceptable.

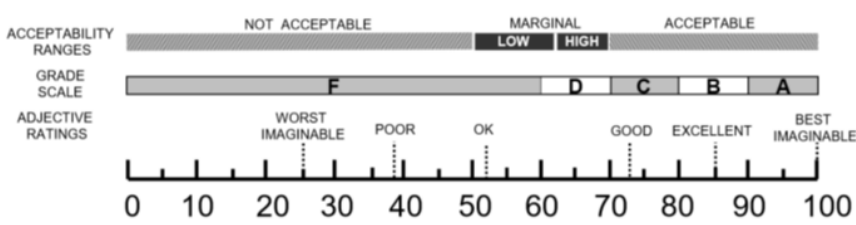

Gambar 1. Skala penilaian akhir System Usability Scale[14]

\section{METODE}

\section{A. Identifikasi Masalah}

Tahapan ini dilakukan identifikasi masalah yang ada pada situs yaitu tidak semua informasi tersedia, seperti informasi satuan kerja yang mana ketika diakses hanya menampilkan halaman kosong yang kadaluarsa, informasi seputar survey IKM yang hanya menampilkan halaman kosong dan server yang lambat dalam waktu tertentu ketika akan mengakses situs tersebut. Kondisi situs seperti ini biasanya akan berdampak kepada pengalaman pengguna.

\section{B. Studi Literatur}

Tahapan studi literatur memungkinkan penulis untuk mendapatkan landasan teori yang diperoleh dari jurnaljurnal dan buku-buku yang digunakan untuk menunjang proses keberhasilan penelitian dan mempunyai dasar teori keilmuan yang baik.

\section{Pengumpulan Data}

Data yang dikumpulkan pada penelitian ini didapatkan dari 30 orang partisipan. Para partisipan dipilih berdasarkan 3 tingkatan keahlian penggunaan komputer dengan kriteria sebagai berikut : 1) tingkatan ahli diambil menurut aktifitas pemakaian internet dan penggunaan komputer maupun laptop yang lebih sering, 2) tingkatan menengah diambil berdasarkan bisa memahami pemakaian internet tetapi aktifitas penggunaannya tidak lebih sering dari level ahli, 3) tingkatan awam berdasarkan pemahaman yang kurang terhadap penggunaan internet dan aktifitas yang kurang terhadap pemakaian teknologi. Para partisipan akan menjalankan 10 task scenario yang telah dirancang sesuai dengan fungsi yang dimiliki oleh situs. Task scenario yang diberikan antara lain:

1. Skenario mencari alamat Kanwil Kemenkumhan Jambi di situs

2. Skenario mencari tahu visi dan misi Kanwil Kemenkumhan Jambi 
3. Skenario melihat profil pejabat Kanwil Kemenkumhan Jambi

4. Skenario mencari syarat naturalisasi

5. Skenario melihat prosedur penggantian paspor

6. Skenario mencari informasi pengambilan benda sitaan negara

7. Skenario layanan pelaporan masyarakat

8. Skenario menampilkan register pindah pegawai

9. Skenario melihat peraturan lembaga lain

10. Skenario merubah bahasa pada situs

Pemilihan 30 partisipan dirasakan cukup untuk mendapatkan rata-rata $99 \%$ kesalahan pada situs tersebut.

Tabel 2. Jumlah Relatif Masalah Yang Di Temukan Terhadap Jumlah Peserta [10]

\begin{tabular}{|c|c|c|}
\hline $\begin{array}{c}\text { Jumlah } \\
\text { Partisipan }\end{array}$ & $\begin{array}{c}\text { Minimal \% } \\
\text { Ditemukan }\end{array}$ & $\begin{array}{c}\text { Mean \% } \\
\text { Ditemukan }\end{array}$ \\
\hline 5 & 55 & 85.55 \\
\hline 10 & 82 & 94.868 \\
\hline 15 & 90 & 97.050 \\
\hline 20 & 95 & 98.4 \\
\hline 30 & 97 & 99.0 \\
\hline 40 & 98 & 99.6 \\
\hline 50 & 98 & 100 \\
\hline
\end{tabular}

Setelah menyelesaikan task scenario yang diberikan, para partisipan akan diminta untuk mengisi kuesioner System Usability Scale dengan pernyataan seperti yang dapat dilihat pada Tabel 1 sesuai dengan pengguna rasakan saat berinteraksi dengan situs.

\section{Analisis Data}

Data yang didapat melalui task scenario akan ditabulasi untuk dianalisa persentase tingkat keberhasilan dari tiap skenario oleh masing-masing pengguna. Data kuisioner System Usability Scale diolah untuk mendapatkan skor penilaian dari 0-100. Adapun formula perhitungan skor kuisioner SUS adalah sebagai berikut [11]:

Skor System Usability Scale $=$ $((R 1-1)+(5-R 2)+(R 3-1)+(5-R 4)+(R 5-1)+(5-R 6)+$ $(R 7-1)+(5-R 8)+(R 9-1)+(5-R 10)) * 2.5)$.

\section{HASIL}

\section{A. Evaluasi Task Scenario}

Persentase penyelesaian skenario dari masing-masing kelompok menunjukkan adanya keseragaman. Task scenario T4 yaitu "Mencari syarat naturalisasi" di situs adalah yang tingkat keberhasilannya paling rendah.

Tabel 3. Persentase Penyelesaian Task Scenario Berdasarkan Keahlian Pengguna

\begin{tabular}{|c|c|c|c|}
\hline $\begin{array}{c}\text { Task } \\
\text { Scenario }\end{array}$ & Ahli & Menengah & Awam \\
\hline T1 & $80 \%$ & $70 \%$ & $70 \%$ \\
\hline T2 & $100 \%$ & $90 \%$ & $70 \%$ \\
\hline T3 & $100 \%$ & $70 \%$ & $60 \%$ \\
\hline T4 & $60 \%$ & $60 \%$ & $50 \%$ \\
\hline T5 & $90 \%$ & $80 \%$ & $70 \%$ \\
\hline T6 & $90 \%$ & $80 \%$ & $50 \%$ \\
\hline T7 & $90 \%$ & $90 \%$ & $40 \%$ \\
\hline T8 & $90 \%$ & $80 \%$ & $50 \%$ \\
\hline T9 & $100 \%$ & $80 \%$ & $70 \%$ \\
\hline T10 & $100 \%$ & $100 \%$ & $60 \%$ \\
\hline Rata-rata & $90 \%$ & $71 \%$ & $59 \%$ \\
\hline
\end{tabular}

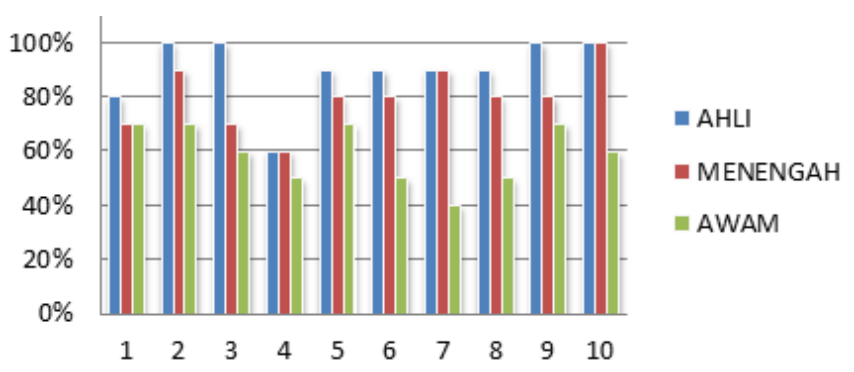

Gambar 2. Grafik Persentase Penyelesaian Task Scenario oleh Partisipan Berdasarkan Tingkat Keahlian

Analisa lebih lanjut dilakukan terhadap Task Scenario 4 menunjukkan adanya kesulitan yang dialami oleh partisipan dalam menemukan tautan menuju halaman mengenai informasi syarat naturalisasi pada situs. Daftar menu tautan yang terlalu banyak dengan ukuran font yang kecil, dan pemilihan warna latar menu transparan mengakibatkan tampilan teks yang terlihat tumpang tindih dengan latar belakang carousel. Kombinasi ini berpotensi menurunkan pengalaman pengguna.

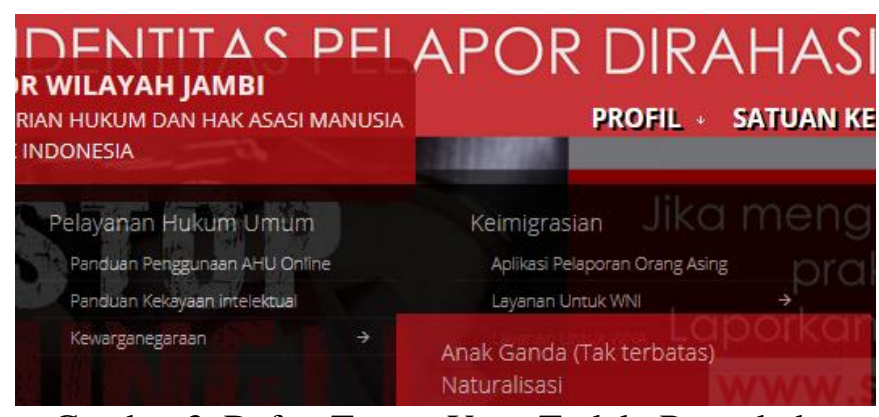

Gambar 3. Daftar Tautan Yang Terlalu Banyak dan Warna Transparan Menurunkan Pengalaman Pengguna

Partisipan yang gagal menemukan tautan untuk mencari tahu informasi layanan publik syarat naturalisasi juga kesulitan dalam menemukan fungsi pencarian dalam situs. Kesulitan ini terjadi dikarenakan faktor penentuan komposisi warna ikon maupun warna carousel yang mengakibatkan sulit terlihatnya ikon tersebut. 


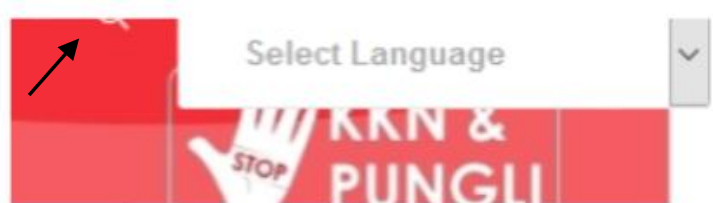

Gambar 4. Kombinasi Warna dan Ukuran Ikon Search Menyulitkan Untuk Terlihat

Pengguna awam terlihat mengalami kendala yang cukup besar dalam menelusuri isi situs. Ini ditunjukkan dengan rata-rata persentase penyelesaian task scenario yang hanya $60 \%$.

\section{B. Evaluasi Kuesioner SUS}

Berdasarkan tingkatan keahlian menggunakan komputer menunjukkan adanya keseragaman dalam skor yang dihasilkan.

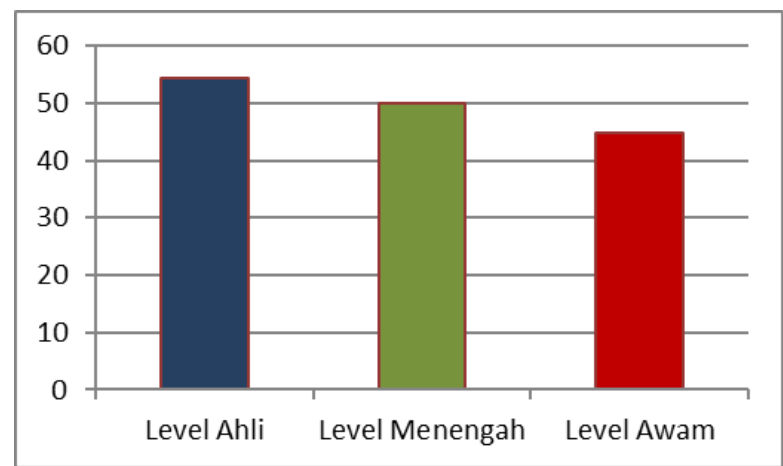

Gambar 5. Rata-rata skor kuesioner SUS Berdasarkan Tingkat Keahlihan Menggunakan Komputer

Skor yang dihasilkan oleh pengguna di semua tingkatan keahlian menunjukkan rata-rata 49.67. Skor ini setara dengan nilai $\mathrm{F}$ pada grade scale, dan juga setara dengan poor pada adjectives rating.

Tabel 4. Rata-rata Skor SUS Tiap Tingkatan Keahlian

\begin{tabular}{|c|c|c|}
\hline Ahli & Menengah & Awam \\
\hline 54.25 & 50 & 44.75 \\
\hline
\end{tabular}

\section{KESIMPULAN}

Evaluasi kuesioner SUS menunjukkan rendahnya skor penilaian pengguna secara merata di tiap tingkat keahlian. Dengan rata-rata skor di bawah 50 setara dengan nilai $F$ pada skala penilaian nilai huruf. Perbaikan-perbaikan perlu dilakukan berdasarkan hasil temuan dari evaluasi usability.

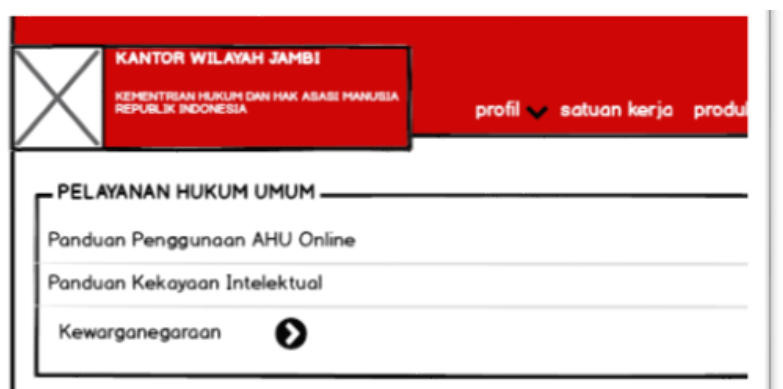

Gambar 6. Rekomendasi Rancangan Halaman Khusus Informasi Layanan Publik

Evaluasi yang telah dilakukan menunjukkan adanya kesulitan yang dialami oleh pengguna. Proses mencari informasi layanan publik di situs mengharuskan pengguna menelusuri banyaknya daftar menu ditampilkan. Terlebih lagi paduan penggunaan warna transparan yang membuat tampilan tumpang tindih antara daftar menu dengan gambar latar carousel.

Banyaknya informasi layanan publik membuat menu dropdown sebagai media utama pengaksesan informasi tersebut mengakibatkan terjadinya tumpukan daftar yang sangat panjang. Sebaiknya disediakan halaman khusus yang berisi daftar tautan informasi layanan publik sehingga lebih tertata dengan rapi.

Pemanfaatan fitur pencarian yang tersedia pada halaman situs juga tidak optimal dikarenakan ikon yang kecil dan sulit ditemukan.

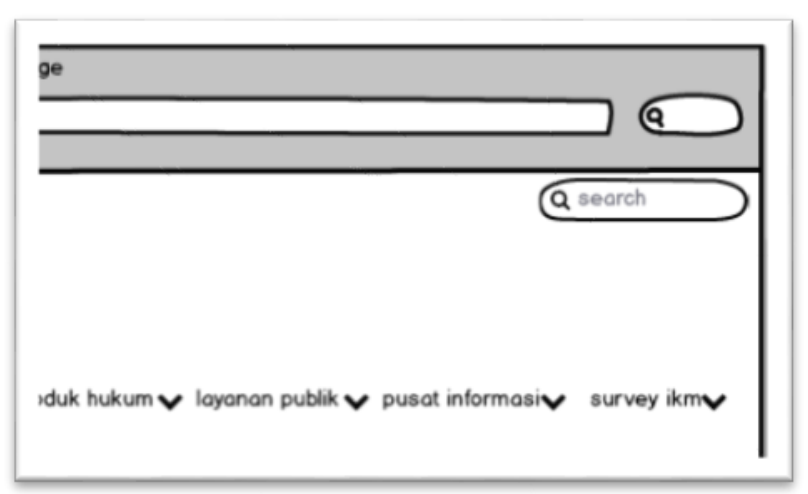

Gambar 7. Rekomendasi Rancangan Menu Pencarian

Fitur pencarian pada situs akan lebih mudah ditemukan jika memiliki bentuk ikon yang lebih mudah terlihat dengan paduan kontras yang baik dan terintegrasi langsung dengan formulir input.

\section{DAFTAR PUSTAKA}

[1] M. Matera, R. Francesca, dan G. T. Carughi, Web usability: Principles and evaluation methods. Berlin, Heidelberg: Springer, 2006.

[2] A. Sonderegger dan J. Sauer, "The influence of design aesthetics in usability testing: Effects on user performance and preceived usability," Appl. Ergon., vol. 3 , no. 41, hal. 403-410, 2010. 
[3] J. Nielsen dan M. Tahir, Homepage usability: 50 websites deconstructed. New Riders Publishing, 2001.

[4] R. Pamungkas dan S. Saifullah, "Evaluasi Kualitas Website Program Studi Sistem Informasi Universitas PGRI Madiun Menggunakan Webqual 4.0," INTENSIF J. Ilm. Penelit. dan Penerapan Teknol. Sist. Inf., vol. 3, no. 1, hal. 22, Feb 2019.

[5] J. Nielsen, Usability inspection methods. ACM, 1994.

[6] C. M. Barnum, Usability testing essentials: ready, set... test! Elsevier, 2010.

[7] J. Nielsen, Designing web Usability: The practice of simplicity. New Riders Publishing, 1999.

[8] A. Bangor, P. T. Kortum, dan J. T. Miller, "An empirical evaluation of the system usability scale," Intl. J. Human-Computer Interact., vol. 24, no. 6, hal. 574-594, 2008.

[9] W. Albert dan T. Tullis, Measuring the user experience: Collecting, Analyzing and Presenting Usability Metrics, Newnes. 2008.

[10] J. Brooke, "SUS-A quick and dirty usability scale," Usability Eval. Ind., vol. 189, no. 194, hal. 4-7, 1996.

[11] J. Sauro dan J. R. Lewis, Quantifying the user experience: Practical statistics for user research. Morgan Kaufmann, 2016.

[12] N. Asnawi, "Pengukuran Usability Aplikasi Google Classroom Sebagai E-learning Menggunakan USE Questionnaire (Studi Kasus: Prodi Sistem Informasi UNIPMA)," Res. Comput. Inf. Syst. Technol. Manag., vol. 1, no. 1, hal. 17-21, 2018.

[13] K. Finstad, "The system usability scale and nonnative english speakers," J. usability Stud., vol. 1, no. 4, hal. 185-188, 2006.

[14] A. Bangor, P. Kortum, dan J. Miller, "Determining what individual SUS scores mean: Adding an adjective rating sclae," J. usability Stud., vol. 4, no. 3, hal. 114-123, 2009. 